\title{
MODIFICATION OF $\beta$-GALACTOSIDASE FOR USE IN ORGANIC MONO-PHASE HEXANOL SYSTEM
}

\author{
Daniela Nikolovska-Nedelkoska, Irina Mladenoska, Filimena Poposka, \\ Eleonora Winkelhausen, Slobodanka Kuzmanova \\ Faculty of Technology and Metallurgy, SS. Cyril and Methodius University, \\ Rudjer Bosković 16, MK-1000 Skopje, Republic of Macedonia \\ kuzman_s@tmf.ukim.edu.mk
}

\begin{abstract}
Different methods for preparation of the Aspergillus oryzae $\beta$-galactosidase were evaluated and the total enzyme activity was determined in hexanol mono-phase system using $p$-nitrophenyl- $\beta$-D-galactoside as a substrate. Several supports such as Acurell EP-100, Amberlite IRC (50), Celite, Dowex, Eupergit C and silica gel were tested in order to select the most suitable matrix for immobilization of the $\beta$-galactosidase for performing transgalactosylation reactions in hexanol. Celite and Amberlite IRC (50) were selected as the most appropriate carriers. Albumin, PEG 6000 , starch and glycine, added prior to the immobilization procedure, acted as stabilizers of the galactosidase. By adding albumin on Celite, a 3.3-fold increase of enzyme activity was achieved. Sodium dodecyl sulphate (SDS), dioctyl sulfosuccinate (AOT), Tween 65 and crown ether were used directly in the reaction medium in order to increase its homogeneity. Addition of SDS to the medium resulted in a 3.65-fold increased activity of the $\beta$ galactosidase deposited on Celite. A micro-emulsion system created by addition of AOT resulted in an increased catalytic activity. The $\beta$-galactosidase showed enhanced total activity with increased water activity in the system having the highest value for the water activity close to the saturation level (0.92).
\end{abstract}

Key words: $\beta$-galactosidase; immobilization; enzyme modification; Amberlite IRC (50); Celite; hexanol mono-phase system

\section{МОДИФИКАЦИЈА НА $\beta$-ГАЛАКТОЗИДАЗА ЗА ПРИМЕНА ВО ОРГАНСКА МОНОФАЗНА СРЕДИНА НА ХЕКСАНОЛ}

Користени беа различни начини на подготовка на ензимот $\beta$-галактозидаза од Aspergillus oryzae за примена во монофазен органски систем со хексанол. Вкупната активност на ензимот на добиените препарати беше следена со употреба на $p$-нитрофенил- $\beta$-галактозид како супстрат за биосинтезата. Неколку материјали, и тоа Acurell EP-100, Amberlite IRC (50), Celite, Dowex, Eupergit C и силика-гел беа тестирани како носачи за имобилизација на ензимот за спроведување на реакција на трансгликозилација во органскиот медиум. Celite и Amberlite IRC (50) беа селектирани како носачи за имобилизација. Модификација на имобилизационите постапки беше спроведена со употреба на адитиви како албумин, PEG 6000, скроб, глицин, кои во улога на стабилизатори беа додавани кон носачот пред имобилизацијата на ензимот. Додавањето на албумин пред депозицијата на ензимот врз носачот Celite резултираше во препарат со речиси 3,3 пати повисока активност во однос на препаратот без албумин. Друга група адитиви, и тоа натриумдодецилсулфат, диоктилсулфосукцинат, Tween 65 и крунест етер, се додавани директно во реакциониот медиум со цел да ја подобрат дисперзијата на ензимот во системот. Присуството на натриумдодецилсулфат во медиумот овозможи зголемување на активноста на имобилизираната $\beta$-галактозидаза за 3,65 пати со депозиција врз Celite. Реверзните мицели добиени со диоктилсулфосукцинатот доведоа до зголемена активност на ензимот. Порастот на активноста на водата во системот, блиска до нивото на заситување $(0,92)$, доведе до зголемување на вкупната активност на имобилизираната $\beta$-галактозидаза.

Клучни зборови: $\beta$-галактозидаза; имобилизација; модификација на ензим; Amberlite IRC (50); Celite; монофазен органски систем 


\section{INTRODUCTION}

Among hydrolytic enzymes, lipases and proteases have been mostly studied for their use in bioorganic synthesis. In this regard, glycosidases have been neglected, until recently, when they attracted attention as catalysts for synthesis of alkylglycosides in non-conventional media. In modern food, chemical and pharmaceutical industry, these products are known as non-ionic surfactants characterized by high surface activity, low toxicity and good biocompatibility [1-3]. Generally, the activity of hydrolases in organic solvents is low compared to their activity in aqueous solutions which is often a limiting factor for an extensive usage of these enzymes as catalyst in biocatalytic synthetic reactions. Several factors might be responsible for the decrease of the enzyme activity in organic media: direct inactivation of the enzyme by the solvent, decreased flexibility of the enzyme due to the low thermodynamic water activity in the organic solvent, extensive mass transfer limitations, etc. [1].

Different approaches have been used to enhance the enzyme activity in organic media [4-6]. Immobilization proved to be a suitable technique for this purpose resulting in preparations with increased dispersibility and consequently with increased activity. Due to the enzyme insolubility in organic media, in most cases there was no need of a strong binding force between the enzyme molecules and the support materials. Hence, the simple immobilization procedures of deposition and adsorption were recommended for immobilization of lipases and proteases when used in organic media $[6,7]$. Another approach to increase the activity of hydrolases in organic media is to enhance the enzyme solubility by creating a homogenous system through reverse micelles [5, 8].

In the present work different methods for modification of the Aspergillus oryzae $\beta$-galactosidase were used in order to create a suitable preparation for hexyl- $\beta$-galactoside synthesis through transglycosylation. The modification comprised of enzyme immobilization on several carriers, modification of the immobilized system itself, modification of the enzyme through the formation of reverse micelles and improvement of the homogeneity of the reaction medium by using several additives.

\section{EXPERIMENTAL}

\section{Materials}

$\beta$-Galactosidase from Aspergillus oryzae, hexanol, $p$-nitrophenyl- $\beta$-D-galactoside (pnpg) and sodium dodecyl sulphate (SDS) were purchased from Sigma Chemicals (St. Louis, USA). The solvent was dried over molecular sieves UOP TYP 3A (pore diameter $0.3 \mathrm{~nm}$ ). Dioctyl sulfosuccinate (AOT), crown ether and Tween 65 were purchased from Fluka Sigma-Aldrich Chemie (Steinheim, Germany), while polyethylene glycol (PEG 6000), glycine and starch were obtained from Merck (Darmstadt, Germany). The support matrices, Celite and Eupergit C were supplied by Fluka Chemie AG (Buchs, Switzerland), Amberlite IRC (50)-H and Dowex 2 X8 by BDH Chemicals Ltd (Poole, England), Accurel EP-100 was obtained from Akzo (Obernburg, Germany) and Silica gel was supplied by Alkaloid (Skopje, R. Macedonia).

The matrices were prepared as follows: Celite was first washed with ethanol to remove organic matters, and after that it was washed several times with deionized water. Between each washing the supernatant was carefully decanted to remove fines. Washed Celite was incubated overnight with 10\% nitric acid at room temperature, rinsed thoroughly with deionized water and finally dried overnight at $80^{\circ} \mathrm{C}$. Amberlite IRC (50)-H, Dowex, Eupergit C and silica gel were washed with distilled water, then with citrate buffer (50 mM, $\mathrm{pH} 4.5)$ and vacuum dried overnight. Accurel EP-100, instead of water, was first washed with ethanol, then rinsed with citrate buffer and vacuum dried. Nitric acid and bovine serum albumin (BSA), were purchased from a local supplier. A $50 \mathrm{mM}$ citrate buffer $(\mathrm{pH}$ 4.5) and $50 \mathrm{mM}$ tris- $\mathrm{HCl}$ buffer ( $\mathrm{pH} \mathrm{8)}$ were used, unless otherwise specified.

\section{Enzyme preparation}

Immobilization of enzyme by adsorption. The enzyme was dissolved in $10 \mathrm{ml}$ citrate buffer and centrifuged. The supernatant was added to $1 \mathrm{~g}$ support and incubated overnight at room temperature and filtered thereafter. Citrate buffer in amount of $1 \mathrm{ml}$ was added and the sample was dried overnight under reduced pressure.

Immobilization of enzyme by deposition. The enzyme was dissolved in $1 \mathrm{ml}$ citrate buffer and mixed with $1 \mathrm{~g}$ support material. The mixture was 
dried under vacuum for $20 \mathrm{~h}$. The enzyme concentrations in the samples were in the range of 0.1 to $24 \mathrm{mg} \beta$-galactosidase per gram support. The enzyme samples containing additive (BSA, glycine, starch or PEG) in a concentration of $8 \mathrm{mg}$ additive/g support were prepared in a similar way. The additive solution was added to the support prior to the immobilization of the enzyme. The preparations were dried overnight under reduced pressure.

Treatment of $\beta$-galactosidase with additives. The enzyme was treated by addition of the anionic surfactant AOT, creating two systems - vacuum dried and reversed micelles. For the vacuum dried samples, $40 \quad$ l enzyme solution (1.8 mg enzyme $/ \mathrm{ml}$ citrate buffer) were added to $2 \mathrm{ml} 0.1 \mathrm{M}$ AOT isooctane solution. After shaking for 3 to $5 \mathrm{~s}$, the solution became transparent and subsequently evaporated, and it was dried overnight under vacuum. The reversed micelles were created by adding $1 \mathrm{ml}$ $0.3 \mathrm{M}$ AOT isooctane solution, $1.92 \mathrm{ml}$ substrate solution (10 mM pnpg in hexanol) and $20 \mu \mathrm{l}$ citrate buffer; the mixture was vigorously shaken for $10 \mathrm{~s}$ and after adding $60 \mu \mathrm{l}$ of the enzyme solution (6 $\mathrm{mg}$ enzyme/ml citrate buffer) it was shaken again.

The additives Tween 65, SDS, AOT, and crown ether were not only used to modify the enzyme, but also to increase the homogeneity of the hexanol mono-phase system. The first three compounds were added in quantity of $1 \%(\mathrm{w} / \mathrm{v})$ and the last in amount of $10 \mathrm{mM}$, but all were added directly to the reaction mixture.

\section{Enzyme activity and protein assay}

The catalytic activity of the $\beta$-galactosidase was determined using $p$-nitrophenyl- $\beta$-D-galactoside as a substrate. The reaction mixture contained $10 \mathrm{mM}$ substrate in hexanol (dried over molecular sieves), enzyme preparation and different amounts $(40-120 \mu \mathrm{l})$ of aqueous citrate buffer to a final reaction volume of $2 \mathrm{ml}$. The water content of the reaction medium was measured by the Karl-Fisher titration method and the corresponding water activity was calculated by an UNIFAC Activity Coefficient Calculator (by Bruce Choy and Danny D. Reible, University of Sydney, Australia, and Lousiana State, USA). The enzymatic reaction was carried out in closed glass vials on an orbital shaker at $50^{\circ} \mathrm{C}$, with vigorous shaking (250 rpm). For analysis, $10 \mu \mathrm{l}$ of the reaction mixture were withdrawn, dissolved in tris- $\mathrm{HCl}$ buffer and the total catalytic activity (hydrolysis+transgalactosylation) of the samples was determined spectrophotometricaly (Varian Cary 50 Scan UV-Visible) by measuring the increase in absorbance at $405 \mathrm{~nm}$. The quantity of substrate depleted was calculated from the amount of para-nitrophenol liberated [9]. The protein content was determined by the Lowry method using bovine serum albumin as a standard. The amounts of $\beta$-galactosidase adsorbed onto the supports were determined by measuring the amount of protein in the solution before and after adsorption.

\section{RESULTS AND DISCUSSION}

\section{Immobilization of the catalyst onto a porous support}

The $\beta$-galactosidase was immobilized on various supports such as Amberlite IRC (50)-H, Eupergit C, Dowex, Accurel EP-100, Celite and silica gel. For the immobilization, both techniques, deposition and adsorption, were employed in order to select the most suitable preparations for the synthesis of alkyl-galactosides through transgalactosylation reaction in mono-phase hexanol system. The enzyme immobilized by deposition onto the supports Celite and Amberlite IRC (50)-H showed noticeable total activity of 0.57 and 0.47 $\mu \mathrm{M} / \mathrm{min} \cdot \mathrm{mg}$ protein, respectively, which were the highest values for the expressed activity among all the preparations tested (Table 1).

Although highly recommended as a carrier of choice for application of the lipases in monophased organic media [6], the Accurel EP-100 polypropylene carrier failed in these experiments, exhibiting much lower total activity than the preparation with other carriers. Compared to Amberlite preparations, the enzyme immobilized on EP100 showed 2 and 5 times lower activity for the adsorbed and the deposited enzyme, respectively. The enzyme immobilized by adsorption on Eupergit $\mathrm{C}$, a carrier which was also recommended for immobilization of glycosidases [4], exhibited relatively low activity which was 2.5 and 3.7-fold lower than the activity of the enzyme immobilized on Ambelite and Celite, respectively. Obviously, Eupergit $\mathrm{C}$ was not suitable for application in a mono-phase hexanol system. 
Table 1

Total activity of $\beta$-galactosidase immobilized on various carriers

\begin{tabular}{lcc}
\hline Matrix & \multicolumn{2}{c}{$\begin{array}{c}\text { Total activity } \\
(\mu \mathrm{M} / \mathrm{min} \text {-mg }\end{array}$} \\
\cline { 2 - 3 } & Depostein $)$ \\
\hline Amberlite IRC (50)-H & 0.471 & Adsorption \\
Accurel EP-100 & 0.098 & 0.1235 \\
Eupergit C & 0.368 & 0.097 \\
Silica gel & 0.004 & 0.000 \\
Dowex & 0.025 & 0.094 \\
Celite & 0.571 & 0.353 \\
Amberlite IRC (50)-H + cross- & 0.176 & \\
linking agent & & \\
\hline
\end{tabular}

Deposition - protein loading of the preparations was 7.2 mg enzyme / g support;

Adsorption - enzyme solution with concentration $6 \mathrm{mg}$ enzyme / $10 \mathrm{ml}$ buffer was used for incubation of $1 \mathrm{~g}$ support

Consequently, Celite and Amberlite were selected as matrices for further investigation. It was assumed that the higher activity of the enzyme on these carriers was due to their suitability for immobilization of highly hydrophilic enzymes such as glycosidases. For catalysis of the synthetic reactions in an organic medium the enzyme needs some small amount of water in order to be catalytically active. Thus, more suitable carriers should be those with lower affinity towards the water layer that surrounds the enzyme molecules. Reslow et al. [10], while evaluating some carriers for enzyme application in unconventional media, found out that the Celite and the Amberlite type resin (XAD4) were indeed the carriers that had low affinity towards the water molecules.

\section{Effect of protein loading on the enzyme activity}

The effect of protein loading in the range of 0 to $24 \mathrm{mg}$ enzyme per g support on the activity of the enzyme immobilized by deposition and adsorption onto the carriers Celite and Amberlite is given in Fig. 1. For the samples prepared by deposition on both supports and for the adsorbed preparation on Amberlite, the protein loading of $0.25 \mathrm{mg}$ enzyme per g support led to the maximal initial reaction rate. The maximal initial reaction rate for the enzyme adsorbed on Celite was observed at pro- tein loading of $6 \mathrm{mg}$ enzyme per g support. The decrease of the enzyme activity beyond these protein loadings indicated the presence of mass transfer limitations. Barros et al. [11], investigating the effect of the protein loading on the activity of $\alpha$ chymotrypsin immobilized on several supports, noticed that Celite was a carrier with low porosity and low available surface area, showing the maximal initial rate at only 2 mg enzyme per g support.

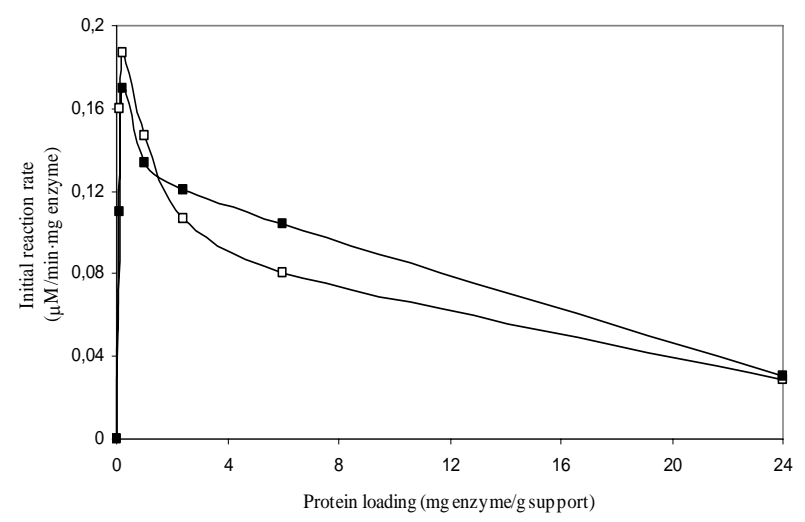

a)

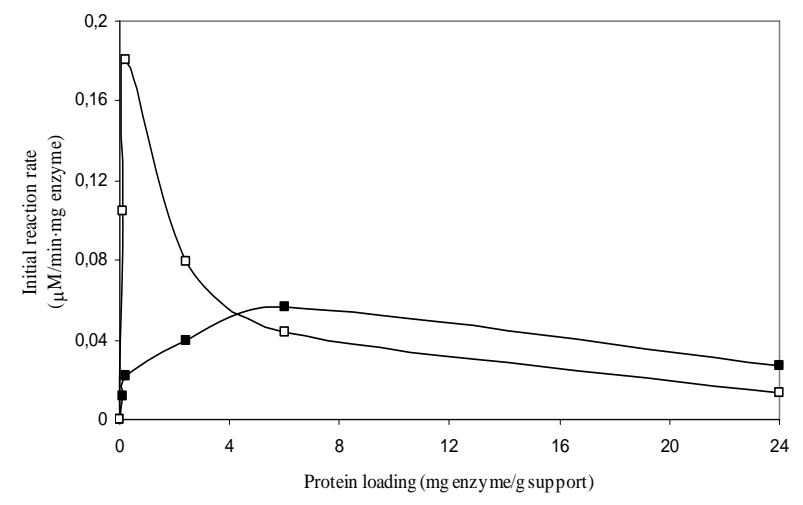

b)

Fig. 1. Effect of protein loading on the initial rate of the reaction catalyzed by $\beta$-galactosidase immobilized onto Amberlite ( $\square$ ) and Celite ( $\square$ ) by (a) deposition and (b) adsorption

The enzyme deposited on both supports exhibited, for the same protein loadings, higher activity than the adsorbed enzyme (Fig. 1). The reason for this could be found in the fact that the soluble components of the commercial galactosidase were washed away from the enzyme during the centrifugation step of the adsorption procedure. In contrast, in the course of the deposition, all nonvolatile components originally present in the aqueous enzyme solution settled onto the matrix influencing the enzyme activity. It has already been reported that even small amounts of buffer salts and 
various compounds used as additives in the preparation procedure of some hydrolytic enzymes might significantly increase the enzyme activity [6, 12].

Regarding the protein recovery (i.e. the retention of the enzyme on the support material at the end of the adsorption procedure), the Celite and Amberlite matrix behaved differently (Fig. 2). Namely, the protein recovery with the Celite dropped sharply above protein loading of $2.4 \mathrm{mg}$ enzyme/g support. Unlike Celite, the protein recovery with Amberlite increased up to $90 \%$ at the protein loading of about $6 \mathrm{mg}$ enzyme/g support, and further on remained almost constant.

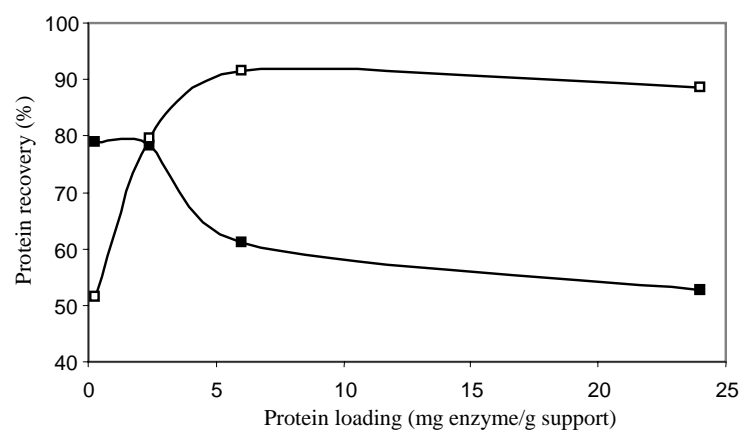

Fig. 2. Protein recovery as a function of the protein loading on Amberlite ( $\square$ ) and Celite (ם)

\section{Effect of additives on the enzyme activity}

In order to increase the activity of the deposited enzyme, several additives such as bovine serum albumin, starch, glycine and PEG 6000 were used. They were added onto the Celite and Amberlite carriers before the enzyme deposition. In order to better view the effect of the additives, the protein loading was kept at $0.25 \mathrm{mg}$ enzyme per gram carrier (Fig. 3). Of all tested compounds, only albumin enhanced the activity of the enzyme immobilized on both carriers by 1.4 and 3.3-fold for Amberlite and Celite, respectively. The effect of albumin might be attributed to its protein nature that leads to the stabilization and prevention of the enzyme deactivation [13]. This effect was not observed when a single amino acid glycine was used. The decreased activity of the immobilized enzyme when other compounds were added could be explained by the fact that some of the water needed by the enzyme was partitioned to the additives [10].

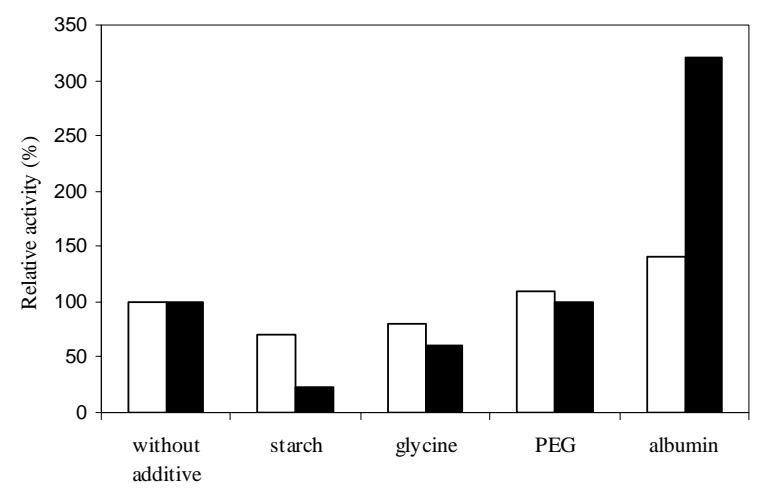

Fig. 3. Effect of additives on the total activity of immobilized enzyme on Amberlite ( $\square$ ) and Celite (

\section{Modification of $\beta$-galactosidase by a surfactant}

The anionic surfactant AOT was used in the $\beta$-galactosidase modification with two different purposes: it played a role of an immobilization matrix, and it solubilized the enzyme creating a microemulsion system. The enzyme deposited on the AOT demonstrated much lower total activity compared to the enzyme in the microemulsion system consisting of AOT/isooctane and water (reversed micelles). Evidently, the increased catalytic activity in organic medium was achieved by creating a homogenous reversed micellar system where the enzyme dispersibility was improved. The total activities of the enzyme deposited on the Amberlite and the Celite carriers, together with the two AOT preparations, are presented in Table 2.

Table 2

Total activity of $\beta$-galactosidase prepared by various procedures

\begin{tabular}{lcc}
\hline \hline Preparation & $\begin{array}{c}\text { Enzyme } \\
\text { concentration } \\
\text { (mg enzyme) }\end{array}$ & $\begin{array}{c}\text { Total activity } \\
(\mu \mathrm{M} / \mathrm{min} \cdot \mathrm{mg} \text { enzyme) }\end{array}$ \\
\hline $\begin{array}{l}\text { Free } \beta \text {-galactosidase } \\
\begin{array}{l}\text { Amberlite IRC (50)-H } \\
\text { deposition }\end{array}\end{array}$ & $0.07^{*}$ & 0.12 \\
$\begin{array}{l}\text { Celite deposition } \\
\begin{array}{l}\text { Celite deposition } \\
\text { (C0.25+BSA) }\end{array}\end{array}$ & 0.25 & 0.19 \\
$\begin{array}{l}\text { AOT deposition } \\
\text { Reverse micelles- } \\
\text { microemulsion }\end{array}$ & 0.25 & 0.17 \\
\hline
\end{tabular}

*40 $\mu \mathrm{l}$ enzyme solution with concentration $1.8 \mathrm{mg} / \mathrm{ml}$ 


\section{Effect of water activity}

The increased water activity had positive effect on the enzyme activity for all samples tested (Fig. 4). It was evident that the enzyme did not show any activity at water activity lower than 0.6. When the water activity of the reaction medium increased from 0.63 to 0.92 , the total activity of the preparation with protein loading of $0.25 \mathrm{mg}$ enzyme/g support increased 12.9 times. This effect may be linked to the enzyme internal flexibility, which is known to increase with increased water activity in organic media [14]. It has already been reported that glycosidases, unlike some other hydrolytic enzymes such as lipases, require relatively high hydration level to exhibit good catalytic activity $[3,15]$.

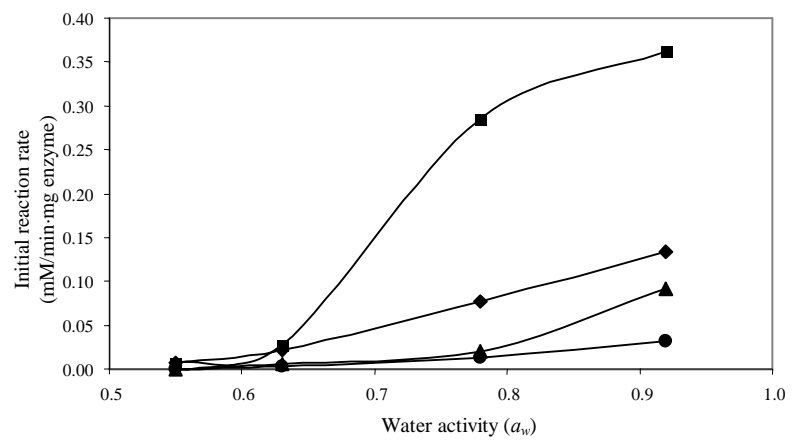

Fig. 4. Influence of the water activity on the initial rate of reaction catalyzed by $\beta$-galactosidase immobilized by deposition on Celite; $(\bullet)$ free enzyme (referent), (•) $24 \mathrm{mg}$ enzyme/g Celite, $(\boldsymbol{\Delta}) 6 \mathrm{mg}$ enzyme/g Celite, $(\boldsymbol{\square}) 0.25 \mathrm{mg}$ enzyme/g (Celite+BSA)

\section{pH effect}

Buffers (citrate, phosphate and tris-HCl buffer) with different $\mathrm{pH}$ value (3-9) were used for dissolving the enzyme prior to its immobilization onto the support in order to investigate the influence of $\mathrm{pH}$ on the total activity of the immobilizates. All preparations, regardless of the immobilization procedures (deposition or adsorption) and the protein loadings, manifested the highest activity in the $\mathrm{pH}$ range of 4.5 to 5.5. Evidently, the buffer salts present in the enzyme solution before its immobilization, played an important role on the enzyme activity when afterwards used in the organic medium. This is related to the "pH memory" effect and proves that it is worthwhile to employ enzymes from an appropriate buffer solution during the immobilization step. It is known that in organic solvents there is no force to affect the change of the enzyme ionization state and thus it remains unchanged from the one in the aqueous solution from which the enzyme was last recovered [16].

\section{Effect of addition of an additive to the reaction mixture}

In an attempt to increase the homogeneity of the hexanol mono-phase system, the additives Tween 65, SDS, AOT, and crown ether were added directly to the reaction media where the enzyme preparation was used (Fig. 5). The presence of SDS in the reaction system yielded a significant increase of 3.65-fold total enzyme activity. The positive effect of this surface active agent may be a result of better dispersion of the enzyme in the medium leading to improved mass transport. On the other hand, it could also be ascribed to the reduced risk of enzyme denaturation by the solvent in the presence of the additive. The positive effect of the addition of SDS in the reaction system of glycosidases as catalysts for hexyl- $\beta$-glycoside synthesis was explained by Hansson et al. [17] with its protecting role against the organic solvent.

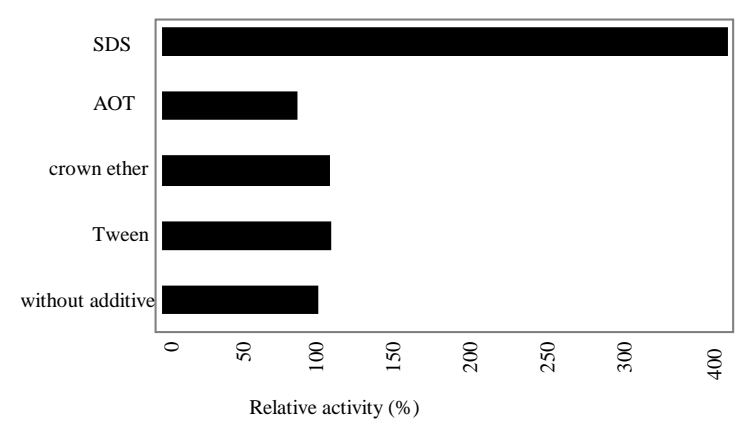

Fig. 5. Effect of some compounds directly added to the reaction mixture on the relative activity of the immobilized A. oryzae $\beta$-galactosidase by deposition on Celite in hexanol monophased system

Acknowledgement. The financial support from the Ministry of Education and Science of the Republic of Macedonia is gratefully acknowledged.

\section{REFERENCES}

[1] J. S. Dordick, Enzymatic catalysis in monophasic organic solvents. Enzyme Microb. Technol., 11, 194-211 (1989).

[2] M. Woudenberg-van Oosterom, H.J.A. van Belle, F. van Rantwijk, R.A. Sheldon, Immobilized $\beta$-galactosidase 
and their use in galactoside synthesis. J. Mol. Catal., 134, 267-274 (1998).

[3] A. Ducret, M. Trani, R. Lortie, Screeninig of various glycosidases for the synthesis of octyl glucoside. Biotechnol. Bioeng., 77 (7), 752-757(2002).

[4] F. van Rantwijk, M. Woudenberg-van Oosterom, R. A. Sheldo, Glycoside-catalysed synthesis of alkyl glycosides. J. Mol. Catal. B: Enzymatic, 6 (6), 511-532 (1999).

[5] O. S. Kouptosova, N. L. Klyachko, A. V. Levashov, Synthesis of alkyl glycosides catalyzed by $\beta$-glycosidases in a system of reverse micelles. Rus. J. Bioorg. Chem., 27 (6), 429-433 (2001).

[6] M. Persson, I. Mladenoska, E. Wehtje, P. Adlercreutz, Preparation of lipases for use in organic solvents. Enzym. Microb. Techn., 31, 833-841 (2002).

[7] M. Persson, E. Wehtje, P. Adlercreutz, Immobilization of lipases by adsorption and deposition: high protein loadings gives lower water optimum. Biotechnol. Lett., 22, 15711575 (2000).

[8] J.A. Arcos, L. Robledo, C. Otero, Stability of a Pseudomonas $s p$. lipase: comparison between solubilased enzyme in reverse micelles and suspended lipase in dry solvents. Biotechnol. Bioeng., 57(5), 505-509 (1997).

[9] T. Hansson, P. Adlercreutz, Optimization of galactooligosaccharide production from lactose using $\beta$-glycosidases from hyperthermophiles. Food Biotechnol., 15: 79-97 (2001).

[10] M. Reslow, P. Adlercreutz, B. Mattiasson, On the importance of the support material for bioorganic synthesis. Eur. J. Biochem., 172, 573-578 (1988).
[11] R. Barros, E. Wehtje, P. Adlercreutz, Mass-transfer studies on immobilized $\alpha$-chymotrypsin biocatalists prepared by deposition for use in organic medium. Biotechnol. Bioeng., 59(3), 364-373 (1998).

[12] Y. Khmelnitsky, S. Welch, D. Clark, J. S. Dordick, Salts dramatically enhance activity of enzymes suspended in organic solvents. J. Am.Chem. Soc., 116, 2647-8 (1994).

[13] E. Wehtje, P. Adlercreutz, B. Mattiasson, Improved activity retention of enzymes deposited on solid supports. Biotechnol. Bioeng., 41, 171-178 (1993).

[14] R. Affleck, Z.-F. Xu, V. Suzawa, K. Focht, D.S. Clark, J.S. Dordick, Enzymatic catalysis and dynamics in lowwater environments. Proc. Natl. Acad. Sci. USA, 89, 1100-1104 (1992).

[15] I. Mladenoska, D. Nikolovska Nedelkoska, E. Winkelhausen, S. Kuzmanova, Aspergillus oryzae- $\beta$-galactosidase - an efficient catalyst for alkyl- $\beta$-galactoside synthesis in organic mono-phase system. Maced. J. Chem. Chem. Eng., 26 (1), 17-24 (2007).

[16] A. Zaks, A. M. Klibanov, Enzyme-catalyzed processes in organic solvents. Proc. Natl. Acad. Sci. USA., 82, 31923196 (1985).

[17] T. Hansson, E. Wehtje, P. Adlercreutz, Enzymatic synthesis of hexyl glycosides from lactose at low water activity and high temperature using hyperthermostable $\beta$ galactosidases. Biocatal. Biotrans., 20, 167-178 (2001). 